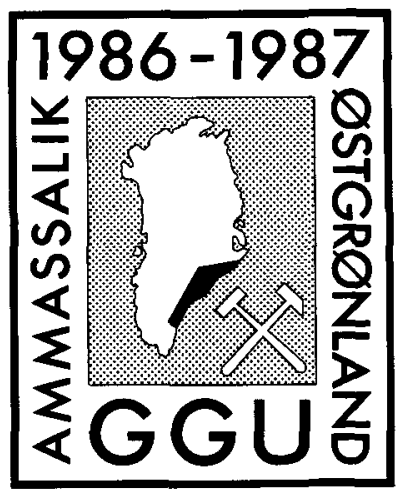

\title{
The Blokken gneisses: a re-appraisal
}

\author{
P. R. Dawes, C. R. L. Friend, A. P. Nutman and \\ N. J. Soper
}

A group of quartzo-feldspathic gneisses - the Blokken gneisses - is described in the literature as a syn-tectonic igneous suite intruded into the central part of the Nagssugtoqidian mobile belt of South-East Greenland in early Proterozoic time. The gneisses are reported to be transgressive to early structures (Nag. 1) and to show only later (Nag. 2) tectonic fabrics. Field data are at variance with this interpretation. No grounds exist for maintaining the gneisses in question as a distinct unit separable from the regional Archaean gneisses. Consequently the term should be abandoned.

\section{Introduction}

In early descriptions of the Nagssugtoqidian mobile belt of South-East Greenland, the gneiss complex which forms the main part of the belt was considered to consist largely of Archaean rocks reworked in Proterozoic time (Andrews et al., 1973; Bridgwater, 1976). Field work in 1976 and 1977 (Bridgwater et al., 1977, 1978b) supported by preliminary isotopic work, led to a change of interpretation and a group of gneisses - the Blokken gneisses - was delimited as a post-Archaean addition to the crust (Bridgwater et al., 1978a) (figs 1, 2). In regional reviews of the mobile belt (Bridgwater \& Myers, 1979; Myers, 1984, 1987) the Blokken gneisses have featured as a suite of diorites, tonalites and granodiorites representative of a magmatic period about 2400 Ma ago. Because magmatism of this age was unknown from other parts of the North Atlantic craton, the Blokken gneisses were investigated by a variety of isotopic techniques in the period 1979 to 1986 (D. Bridgwater, personal communication, 1987). However, the results of these studies have remained unpublished. The results carry the important implication that the suite of samples used in the chemical work (from Blokken - see fig. 1) represent Archaean and not Proterozoic material.

In this paper we review the geology of the Blokken gneisses based on regional mapping in 1986.

\section{Definition, distribution and age}

The first description of the Blokken gneisses as a possible separate unit within the gneiss complex is given in Bridgwater et al. $(1977$, p. 77$)$, where it is stated "Gneisses from the islands south and east of Kungmiut are relatively little affected by younger deformation and preserve many primary intrusive features. They appear to have been derived from a syn-tectonic calc-alkaline suite of relatively mafic tonalites and granodiorites with minor amounts of hornblende diorite and feldsparphyric granodiorite". The rocks were not specifically named, neither were they given a distinguishing signature on the geological sketch map illustrating the report. The gneisses were depicted as an integral part of the regional gneiss complex. The type area of this relatively mafic gneiss unit from which the above description was made, is along the coast south-east of Blokken, a prominent mountain on the westernmost part of the large island east of Angmagssalik Fjord (fig. 1), (D. Bridgwater, personal communication 1986).

Following initial $\mathrm{Pb}-\mathrm{Pb}$ whole-rock age dating work, it was suggested that the rocks along the Blokken coast represented an independent and previously unknown early Proterozoic addition of new mantle-derived material in the central part of the mobile belt and the name Blokken gneisses was introduced (Bridgwater et al., $1978 \mathrm{a}$, p. 11). On published maps the Blokken gneisses were shown to occupy islands of the outer coast northeast of Ammassalik between Angmagssalik Fjord and Sermiligâq (fig. 1), first as a diffuse mass without boundaries (Bridgwater et al., 1978a, fig. 1) and then as a cross-cutting unit with sharp boundaries (Bridgwater \& Myers, 1979, fig. 1; Pedersen \& Bridgwater, 1979, fig. 1) (fig. 2, this paper). It was noted, however, that "The full extent of the Blokken gneisses is not known and may prove very difficult to map since when deformed by younger tectonic events they closely resemble the Archacan gneisses" (Bridgwater \& Myers, 1979, p. 13). The main outcrop of Blokken gneiss was consid- 


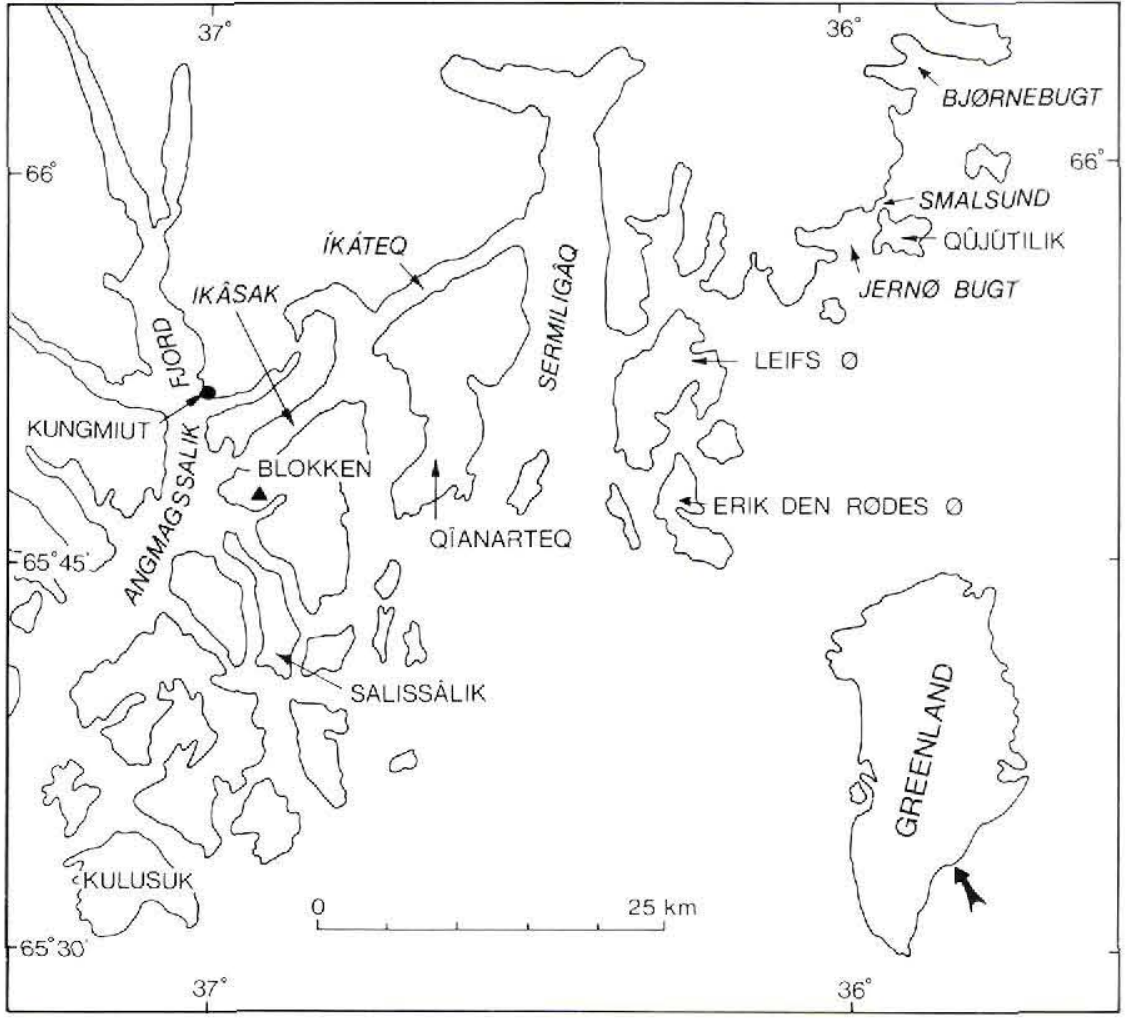

Fig. 1. Location map of the area around Blokken, South-East Greenland. For outcrop of Blokken gneisses and regional location see fig. 2. ered to be about $350 \mathrm{~km}^{2}$ but the unit was surmised to have a greater areal extent, for example around Smalsund and the island of Qûjûtilik (fig. 1).

On lithological grounds, the Blokken gneisses were

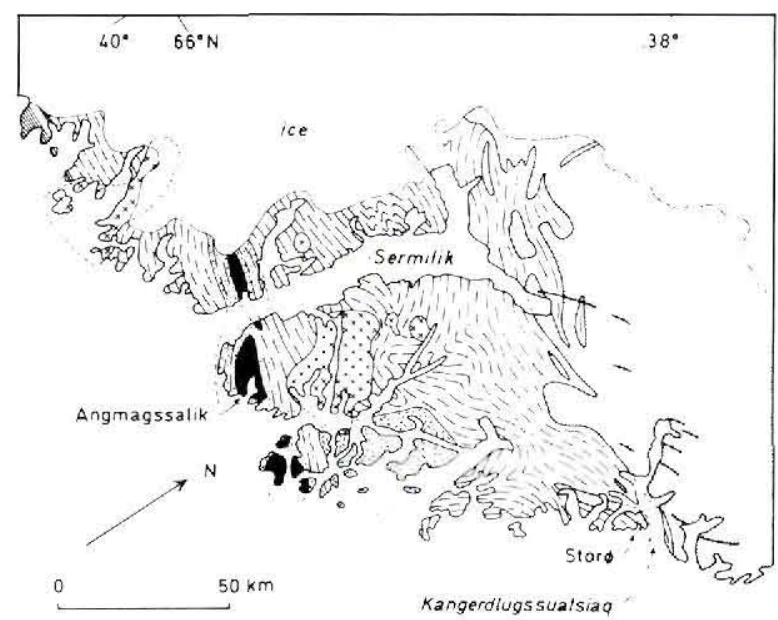

Fig. 2. Geological sketch map of the Ammassalik region, showing in the central coastal area the main outcrop of the Blokken gneisses (random dash ornament). Illustration is reproduced from Bridgwater \& Myers (1979) and is part of fig. 1 of that paper. Bridgwater et al. (1978a, fig. 1) indicate also Blokken gneiss forming the island of Qûjûtilik (for location see fig. 1). said to be separable from the surrounding Archaean gneisses by "... the common preservation of primary igneous textures and the lack of evidence that they were affected by an early granulite facies event" (Bridgwater \& Myers, 1979, p. 13). Additionally, when compared to the Archaean rocks to the north, the Blokken gneisses were thought to be comparatively free from inclusions of basic material, more hornblende-rich and, where supracrustal rafts occur “.... these are generally well-preserved and less brecciated than comparable units in the Archaean complex" (Bridgwater et al., 1978a, p. 11).

The preliminary $\mathrm{Pb}-\mathrm{Pb}$ isotopic data mentioned earlier and referred to in Bridgwater et al. (1978a) was quoted as a whole-rock age of $c .2350 \mathrm{Ma}$ in Bridgwater \& Myers (1979) and Pedersen \& Bridgwater (1979). On this evidence it was suggested that the Blokken gneisses could not have been derived from sialic rocks formed much before $2400 \mathrm{Ma}$; the age was interpreted as that of separation of the Blokken magma from a more basic source (Bridgwater et al., 1978a, p. 11).

Thus the gneisses came to hold a key position in the chronological history of the 'Nagssugtoqidian' mobile belt representing a distinct period of calc-alkaline magmatism. Shown as a major cross-cutting Proterozoic intrusion (Pedersen \& Bridgwater, 1979; Bridgwater \& Myers, 1979; see fig. 2), the Blokken gneisses were 
interpreted in the evolutionary model as post-dating the early deformation (so-called 'Nag. 1'), metamorphism and basic magmatism at c. $2600 \mathrm{Ma}$, but pre-dating the emplacement of the Charcot Fjelde dykes and the later ('Nag. 2') deformation (Myers, 1984, 1987). To the west the Blokken gneisses are cut by major post-tectonic intrusions which have yielded dates of around $1600 \mathrm{Ma}$.

\section{New field data}

The information presented in the previous section indicates that at the onset of the 1986 field work, there existed two scenarios for the Blokken gneisses:

(1) the published view that the gneisses represent a major early Proterozoic sialic addition to the crust, and

(2) unpublished chemical data (D. Bridgwater, personal communication, 1987) suggesting that the gneisses, at least at Blokken itself, represent but a mafic variety of Archaean gneiss not separable geochronologically from the regional gneiss complex.

Clearly, the field evidence for the age of the Blokken gneisses relative to the other units within the mobile belt needed reinvestigation. This was carried out in 1986 as part of the regional mapping programme. Two independent two-man teams (PRD-NJS and CRLF-APN) worked into the area of the Blokken gneisses from the north and south respectively. No grounds were found to separate the gneisses within the designated Blokken area (fig. 2) from the regional grey gneiss complex of the Ammassalik region, and no contacts of plutonic bodies within the gneiss complex were found. All structures within the Blokken gneisses form a continual structural entity and no major discordances of regional structures were recognised.

The gneisses of the Blokken area form a suite of well-foliated and banded quartzo-feldspathic rocks ranging from rather dark, hornblende-rich, veined and banded dioritic gneisses to grey, biotite-rich, granodioritic gneisses and are clearly of multiphase type (fig. 3). Many areas of very pale gneiss occur which are distinctly quartz-poor and may grade into anorthositic rocks. Gradations also occur from the well-foliated and banded rocks to more homogeneous varieties that in some exposures at least show evidence of strong mobilisation. Many of these occurrences are agmatitic. Commonly, the blocks are composed of mafic rock, in places undoubtedly metadyke material (see below), set in a paler coloured gneiss. These outcrops resemble the Blokken gneiss as described by Bridgwater el al. (1977. $1978 \mathrm{a}, \mathrm{b})$ from the type area south-east of Blokken.

Throughout the Blokken area the gneisses contain abundant basic inclusions as well as rocks of supra-

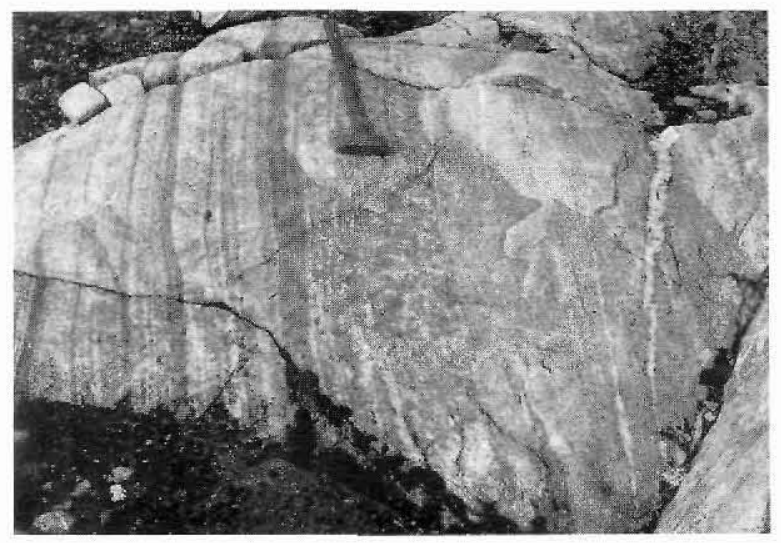

Fig. 3. Grey multiphase gneiss showing banding and late leucocratic veins. North side of Ikâsak.

crustal origin. Commonly the basic material is in the form of concordant to distinctly discordant amphibolitic sheets interpreted as dykes. These show folding and all stages of break-up and boundinage, as commonly found in the reworked Archaean gneisses elsewhere in the Ammassalik region. Some of the bodies are in excess of $100 \mathrm{~m}$ thick and are veined by leucocratic material and grade into agmatites. Relict dyke cores preserve such features as retrogressed eclogitic assemblages (Nutman $\&$ Friend, this volume) or primary igneous mineralogies, surrounded by foliated amphibolite. Many are garnet-bearing and some have sinuous forms and irregular contacts of the type interpreted by previous workers as indicating emplacement into partially melted country rock.

Another group of amphibolites are typically rusty weathering and commonly associated with paragneisses that form continuous units within the grey gneiss com-

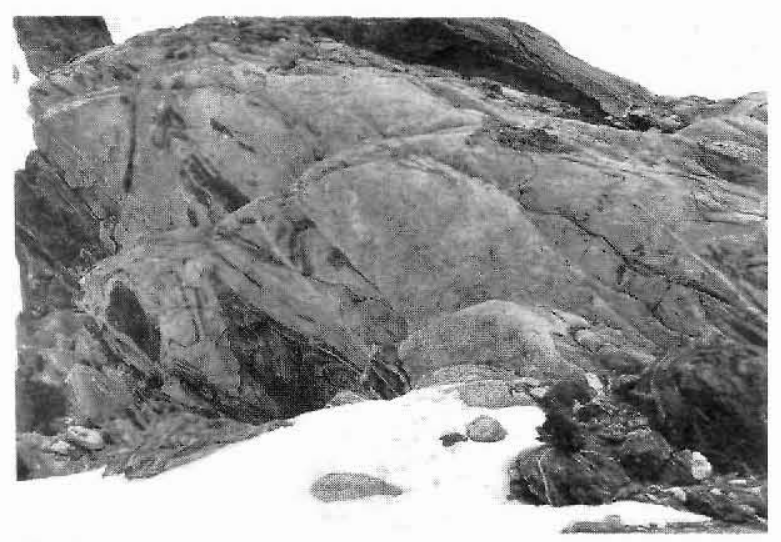

Fig. 4. Typical outcrop from the northern part of the Blokken area showing veining and breakup of amphibolite by pale orthogneiss, with a late pegmatite sheet. Width of fold just above the snow is $1.5 \mathrm{~m}$. Northern Qîanarteq. 
plex. Many of these amphibolites are striped or compositionally layered, features which may represent transposed igneous structures. One supracrustal unit several hundred metres thick, composed of amphibolite, biotite schist, garnet-sillimanite-kyanite schist, quartzite and subsidiary marble, interleaved with grey gneiss and some anorthosite bands, crosses Blokken island and a similar unit is present on Erik den Røde $\emptyset$, Leif $\emptyset$ and the mainland to the north. These appear to be part of the belt of supracrustal units which occur in the grey gneiss complex between Sermilik and the outer coast (fig. 1). They are shown on the map in Wright et al. (1973) although the percentage of supracrustal rocks in the gneisses is much lower than inferred by those authors. Many rusty zones, probably accidentally interpreted as supracrustal rocks prove, on closer inspection, to be rusty amphibolite (possibly dyke remains) or even rusty sheared zones in the gneisses.

In many areas the gneisses and supracrustal rocks are cut by acid veins, mainly pegmatitic material, many of which are characterised by pink K-feldspar (fig. 4). In places this leucocratic material forms an intense network of veins in which at least two distinct generations of material can be distinguished; early grey to white, weakly foliated pegmatites which in places form an anastomosing network, cut by later pink sheets and veins with mainly planar borders. This late pegmatite phase occupies the coastal area to about $66^{\circ} \mathrm{N}$, between Sermiligâq and Bjørnebugt. Within the outcrop area of Blokken gneiss given by Bridgwater \& Myers (1979) pegmatite is particularly conspicuous on northern Qîanarteq (figs 1, 2, 4).

\section{Conclusions}

In summary, the 1986 field data are at variance with the previously published interpretations in four main respects.

(1) Plutons of tonalite (Blokken gneiss) do not cut across early gneiss fabrics ('Nag. 1' structures) in the northern part of the area (fig. 2). The gneisses and supracrustal rocks form a continuous structural entity with the regional grey gneiss.

(2) The rocks designated as Blokken gneisses have a complex structural history which cannot be distinguished from that of the surrounding gneiss complex. The view that the Blokken gneisses show only 'Nag. 2' structures cannot be sustained.

(3) Igneous textures are not commonly preserved. On a regional scale the only feature of igneous origin which is preserved in the gneiss is the polyphase nature of the precursor, now reflected in the banding; on outcrop scale apparent intrusive features may reflect partial melting.

(4) Part of the Blokken gneisses, at least, was affected by granulite facies metamorphism; for example, brownweathering, retrogressed gneisses form the main part of the island of Qûjûtilik. In addition, blebby textured gneisses (Bridgwater et al., 1977) regarded as characteristic of retrogressed granulite facies, is a common feature particularly in the northern part of the area.

In conclusion, we can find no field criteria by which the gneisses of the Blokken area can be identified as plutonic rocks separable from the Archaean grey gneiss complex of the region. Therefore the term should be abandoned as a chronostratigraphic unit.

It should be stressed that outcrops of dioritic and tonalitic gneisses similar to those at Blokken occur throughout the grey gneiss complex as far north as the northern boundary zone. All these outcrops, like the isotopically dated gneisses at Blokken, are regarded as Archaean in age. However, there is no doubt that the regional grey gneisses represent a multiphase complex, the future detailed mapping of which, supported by petrological and geochemical work, may result in the regional distinction of 'older' and younger' gneissic phases. Indeed, some gneisses and dioritic/tonalitic rocks in the region have recently yielded Proterozoic $\mathrm{Sm}-\mathrm{Nd}$ model ages, but this is not the case for a sample of 'Blokken' gneiss from the type locality at Blokken (Kalsbeek \& Taylor, this volume). 